\title{
Under-Reporting Of Returns By Alternative Asset Funds
}

Jeffry Haber, Iona College, USA

Andrew Braunstein, Iona College, USA

\begin{abstract}
Self-reported interim rates of return have always drawn a skeptical eye. Alternative assets have generally provided the least transparency of any investment class, and thus the reported returns have often been considered suspect. A previous study compared the reported returns for a sample of alternative asset funds to the "true" returns (with the "true" return being defined as the rate of return needed to equate the cash flows from the investment), and found that the alternative asset funds generally provided accurate returns. This paper (using the same data set) examines the issue from a different perspective, and concludes that every single alternative asset fund in the sample actually under-reported the rate of return.
\end{abstract}

Keywords: Alternative assets; returns; reported returns; transparency

\section{INTRODUCTION}

$\mathrm{n}$ a previous paper (Haber, Braunstein, Mangiero, Journal of Investing, 2010), a comparison was made between the self-reported interim rates of return and the "true" rates of return for a set of alternative asset funds (with the "true" rate of return defined as the rate of return necessary to equate the cash flows in an alternative investment). Alternative assets include a number of investment types (hedge funds, venture capital, private equity, real estate, oil and gas, natural resources). All possess limited transparency, and except for hedge funds, possess limited lives and utilize capital calls. The limited life is a desirable trait for this study.

Alternative assets are generally constructed through limited partnership vehicles, where the investor commits to a certain maximum contribution during the life of the fund. The investment fund "calls" for funds as investment opportunities are identified, and the investor remits these funds. At some point during the fund's life cycle, the holdings are liquidated and funds are returned to the investor. The "calls" represent the investor's cash flow to the fund, and the "distribution" represents the fund's return of money back to the investor. Regardless of the self-reported interim rates of return (which are usually provided quarterly), the true measure of investment return is a comparison of the cash provided versus the cash returned.

Since the funds used in the previous study had limited lives, usually from $10-12$ years, we were able to calculate a true return based on the cash flows. The results for the reported and true returns (annual) are presented in Figure 1.

Of the 14 funds utilized in the study, 7 under-reported the returns (as defined in the study), and in one case, the reported and true returns were the same.

\section{METHODOLOGY OF THE CURRENT STUDY}

Subsequent to the completion of the prior study, we decided to take a closer look at the cash flows for the various funds in our sample. For example, the cash flows (quarterly) for Fund $\mathrm{L}$ are shown as Figure 2. 
Figure 1

\begin{tabular}{|c|c|c|}
\hline & \multicolumn{2}{|c|}{ Rate of Return } \\
\hline Fund & Reported & 3.48 \\
\hline L & 7.92 & 68.91 \\
\hline AA & 76.20 & 11.93 \\
\hline CC & 10.47 & 11.03 \\
\hline KK & 8.93 & 62.19 \\
\hline DD & 71.79 & 45.67 \\
\hline K & 48.80 & 22.99 \\
\hline C & 22.99 & 15.66 \\
\hline N & 13.19 & 20.77 \\
\hline P & 12.71 & 34.45 \\
\hline S & 33.55 & 24.25 \\
\hline W & 18.13 & 19.51 \\
\hline X & 12.40 & 22.82 \\
\hline
\end{tabular}

Figure 2

\begin{tabular}{|c|c|c|}
\hline Fund & Contribution & Distribution \\
\hline $\mathrm{L}$ & 20,000 & 0 \\
\hline $\mathrm{L}$ & 60,000 & 0 \\
\hline $\mathrm{L}$ & 0 & 0 \\
\hline $\mathrm{L}$ & 60,000 & 0 \\
\hline $\mathrm{L}$ & 40,000 & 0 \\
\hline $\mathrm{L}$ & 80,000 & 0 \\
\hline $\mathrm{L}$ & 81,000 & 0 \\
\hline $\mathrm{L}$ & 0 & 0 \\
\hline $\mathrm{L}$ & 80,000 & 0 \\
\hline $\mathrm{L}$ & 160,000 & 0 \\
\hline $\mathrm{L}$ & 139,000 & 0 \\
\hline $\mathrm{L}$ & 40,000 & 0 \\
\hline $\mathrm{L}$ & 80,000 & 0 \\
\hline $\mathrm{L}$ & 160,000 & 0 \\
\hline $\mathrm{L}$ & 70,000 & 0 \\
\hline $\mathrm{L}$ & 135,000 & 0 \\
\hline $\mathrm{L}$ & 80,000 & 0 \\
\hline $\mathrm{L}$ & 190,000 & 0 \\
\hline $\mathrm{L}$ & 164,000 & 0 \\
\hline $\mathrm{L}$ & 0 & 0 \\
\hline $\mathrm{L}$ & 0 & 0 \\
\hline $\mathrm{L}$ & 41,000 & 0 \\
\hline $\mathrm{L}$ & 99,900 & 0 \\
\hline $\mathrm{L}$ & 40,100 & 0 \\
\hline $\mathrm{L}$ & 0 & 0 \\
\hline $\mathrm{L}$ & 0 & 0 \\
\hline $\mathrm{L}$ & 180,000 & 0 \\
\hline $\mathrm{L}$ & 0 & 0 \\
\hline $\mathrm{L}$ & 0 & $2,305,735$ \\
\hline $\mathrm{L}$ & 0 & 42,900 \\
\hline $\mathrm{L}$ & 0 & 92,193 \\
\hline $\mathrm{L}$ & 0 & 715,745 \\
\hline $\mathrm{L}$ & 0 & 292,563 \\
\hline Total & $2,000,000$ & $3,449,136$ \\
\hline
\end{tabular}


Figure 3

\begin{tabular}{|c|c|c|c|c|c|}
\hline Fund & Contribution & Distribution & Net Cash Flow & IRR & With IRR \\
\hline $\mathrm{L}$ & 20,000 & 0 & 20,000 & 0.0000 & 20,000 \\
\hline $\mathrm{L}$ & 60,000 & 0 & 80,000 & -0.0719 & 78,562 \\
\hline $\mathrm{L}$ & 0 & 0 & 80,000 & -0.0517 & 77,547 \\
\hline $\mathrm{L}$ & 60,000 & 0 & 140,000 & -0.6456 & 115,347 \\
\hline $\mathrm{L}$ & 40,000 & 0 & 180,000 & -0.4800 & 136,705 \\
\hline $\bar{L}$ & 80,000 & 0 & 260,000 & -0.0802 & 212,360 \\
\hline $\mathrm{L}$ & 81,000 & 0 & 341,000 & -0.0578 & 289,121 \\
\hline $\mathrm{L}$ & 0 & 0 & 341,000 & 0.0203 & 290,588 \\
\hline $\mathrm{L}$ & 80,000 & 0 & 421,000 & 0.0000 & 370,588 \\
\hline $\mathrm{L}$ & 160,000 & 0 & 581,000 & 0.0000 & 530,588 \\
\hline $\bar{L}$ & 139,000 & 0 & 720,000 & 0.0000 & 669,588 \\
\hline $\mathrm{L}$ & 40,000 & 0 & 760,000 & 0.0000 & 709,588 \\
\hline $\mathrm{L}$ & 80,000 & 0 & 840,000 & 0.0000 & 789,588 \\
\hline $\mathrm{L}$ & 160,000 & 0 & $1,000,000$ & 0.0291 & 956,497 \\
\hline $\mathrm{L}$ & 70,000 & 0 & $1,070,000$ & 0.0243 & $1,032,733$ \\
\hline $\mathrm{L}$ & 135,000 & 0 & $1,205,000$ & 0.1640 & $1,215,610$ \\
\hline $\mathrm{L}$ & 80,000 & 0 & $1,285,000$ & 0.1411 & $1,341,312$ \\
\hline $\mathrm{L}$ & 190,000 & 0 & $1,475,000$ & 0.1224 & $1,578,170$ \\
\hline $\mathrm{L}$ & 164,000 & 0 & $1,639,000$ & 0.1064 & $1,788,512$ \\
\hline $\mathrm{L}$ & 0 & 0 & $1,639,000$ & 0.0702 & $1,819,900$ \\
\hline $\mathrm{L}$ & 0 & 0 & $1,639,000$ & 0.0627 & $1,848,427$ \\
\hline $\mathrm{L}$ & 41,000 & 0 & $1,680,000$ & -0.0600 & $1,861,086$ \\
\hline $\mathrm{L}$ & 99,900 & 0 & $1,779,900$ & -0.0578 & $1,932,650$ \\
\hline $\mathrm{L}$ & 40,100 & 0 & $1,820,000$ & -0.0327 & $1,956,622$ \\
\hline $\mathrm{L}$ & 0 & 0 & $1,820,000$ & -0.0291 & $1,942,388$ \\
\hline $\mathrm{L}$ & 0 & 0 & $1,820,000$ & 0.0037 & $1,944,185$ \\
\hline $\mathrm{L}$ & 180,000 & 0 & $2,000,000$ & 0.0019 & $2,125,194$ \\
\hline $\mathrm{L}$ & 0 & 0 & $2,000,000$ & 0.1469 & $2,203,241$ \\
\hline $\mathrm{L}$ & 0 & $2,305,735$ & $-305,735$ & 0.1441 & $-106,186$ \\
\hline $\mathrm{L}$ & 0 & 42,900 & $-348,635$ & 0.1547 & $\begin{array}{l}-154,852 \\
\end{array}$ \\
\hline $\mathrm{L}$ & 0 & 92,193 & $-440,828$ & 0.1507 & $-256,352$ \\
\hline $\mathrm{L}$ & 0 & 715,745 & $-1,156,573$ & 0.1811 & $-1,016,109$ \\
\hline $\mathrm{L}$ & 0 & 292,563 & $-1,449,136$ & 0.1772 & $-1,366,646$ \\
\hline $\mathrm{L}$ & 0 & 0 & $-1,449,136$ & 0.1734 & $-1,425,890$ \\
\hline $\mathrm{L}$ & 0 & 0 & $-1,449,136$ & 0.1718 & $-1,487,132$ \\
\hline $\mathrm{L}$ & 0 & 0 & $-1,449,136$ & 0.1667 & $-1,549,108$ \\
\hline $\mathrm{L}$ & 0 & 0 & $-1,449,136$ & 0.1654 & $-1,613,164$ \\
\hline $\mathrm{L}$ & 0 & 0 & $-1,449,136$ & 0.1608 & $-1,678,013$ \\
\hline $\mathrm{L}$ & 0 & 0 & $-1,449,136$ & 0.1597 & $-1,745,008$ \\
\hline $\mathrm{L}$ & 0 & 0 & $-1,449,136$ & 0.1588 & $-1,814,285$ \\
\hline $\mathrm{L}$ & 0 & 0 & $-1,449,136$ & 0.1581 & $-1,885,994$ \\
\hline $\mathrm{L}$ & 0 & 0 & $-1,449,136$ & 0.1569 & $\begin{array}{l}-1,959,972 \\
\end{array}$ \\
\hline $\mathrm{L}$ & 0 & 0 & $-1,449,136$ & 0.1563 & $-2,036,558$ \\
\hline $\mathrm{L}$ & 0 & 0 & $-1,449,136$ & 0.1505 & $-2,113,184$ \\
\hline $\mathrm{L}$ & 0 & 0 & $-1,449,136$ & 0.1501 & $-2,192,481$ \\
\hline $\mathrm{L}$ & 0 & 0 & $-1,449,136$ & 0.1498 & $-2,274,589$ \\
\hline $\mathrm{L}$ & 0 & 0 & $-1,449,136$ & 0.1494 & $-2,359,545$ \\
\hline $\mathrm{L}$ & 0 & 0 & $-1,449,136$ & 0.1491 & $-2,447,497$ \\
\hline $\mathrm{L}$ & 0 & 0 & $-1,449,136$ & 0.1490 & $-2,538,667$ \\
\hline $\mathrm{L}$ & 0 & 0 & $-1,449,136$ & 0.1489 & $-2,633,169$ \\
\hline $\mathrm{L}$ & 0 & 0 & $-1,449,136$ & 0.1487 & $-2,731,057$ \\
\hline $\mathrm{L}$ & 0 & 0 & $-1,449,136$ & 0.1486 & $-2,832,515$ \\
\hline $\mathrm{L}$ & 0 & 37,000 & $-1,486,136$ & 0.1466 & $-2,974,683$ \\
\hline $\mathrm{L}$ & 0 & 775 & $-1,486,911$ & 0.1466 & $-3,084,509$ \\
\hline
\end{tabular}


One can see that, overall, the fund returned more than was contributed. Recall from Figure 1 that the "true" rate of return was calculated as $3.48 \%$, versus a reported return of $7.92 \%$, leading us to conclude that the fund's returns were "over-reported." When we then applied the reported interim rates of return to the actual cash flows, we obtained the results shown as Figure 3.

Fund $\mathrm{L}$ seemed to be an appropriate fund to look at first, because the contributions and distributions did not overlap - all funds were called prior to any distributions were made. That made it easy to see that the fund, at least initially, actually under-reported the returns. At the point the first distribution was made, the fund should have had $\$ 2,203,241$ available to distribute (the balance of all contributions plus the quarterly reported returns). Not only did the fund distribute more than this, but the fund had excess holdings to the extent that future distributions could be made.

We then set about analyzing the actual extent to which this particular fund had under-reported the returns. We applied a static adjustment to each quarterly reported return. In the case of Fund L, we found (using trial and error) that we had to add $10.70 \%$ to each quarterly return in order for the balance after the last distribution to be zero $(0)$.

\section{EMPIRICAL RESULTS FOR ALL FUNDS}

We applied the same methodology as above to the remaining 13 funds. The necessary static adjustments (to two decimal places) for the entire set of funds are shown as Figure 4 (with the funds in the same order as Figure 1)

\begin{tabular}{|c|c|}
\multicolumn{1}{|c|}{ Figure 4 } & Static Adj. \\
\hline Fund & 10.70 \\
\hline LA & 8.53 \\
\hline CC & 2.99 \\
\hline KK & 5.30 \\
\hline DD & 5.94 \\
\hline K & 8.12 \\
\hline CC & 2.73 \\
\hline M & 5.78 \\
\hline N & 16.84 \\
\hline $\mathrm{P}$ & 6.90 \\
\hline S & 12.92 \\
\hline U & 14.75 \\
\hline $\mathrm{X}$ & 0.00 \\
\hline
\end{tabular}

Note that each of the 14 funds in the sample has a positive static adjustment. This leads to the inference that the reported returns were less than the actual returns in the case of all fourteen funds. This clearly contradicts the results of the previous study, which found that some of the funds had reported returns that were greater than the actual (although by a very small margin in several of the cases).

We sort the static adjustments in descending order in Figure 5.

Figure 6 adds the relevant information from Figure 1 (reported and true returns for the various funds) to Figure 5's display.

From Figure 6, we see that the three funds with the biggest negative difference between reported and true returns in the previous study (i.e., the three funds with the greatest level of under-reported returns) had the largest positive static adjustments in the current study. This seems to provide further evidence that those particular funds did indeed greatly understate the interim rates of return. Also, the two funds with the smallest difference between reported and true returns had the two smallest necessary static adjustments.

Finally, we present the static adjustments for each fund as a percentage of the reported and true rates of return. The results are shown as Figure 7. 
Figure 5

\begin{tabular}{|c|c|}
\hline Fund & Static Adj. \\
\hline & 16.84 \\
\hline $\mathrm{N}$ & 14.75 \\
\hline $\mathrm{U}$ & 12.92 \\
\hline $\mathrm{S}$ & 10.70 \\
\hline $\mathrm{L}$ & 8.53 \\
\hline $\mathrm{AA}$ & 8.12 \\
\hline $\mathrm{K}$ & 6.90 \\
\hline $\mathrm{P}$ & 5.94 \\
\hline $\mathrm{DD}$ & 5.78 \\
\hline $\mathrm{M}$ & 5.49 \\
\hline $\mathrm{X}$ & 5.30 \\
\hline $\mathrm{KK}$ & 2.99 \\
\hline $\mathrm{CC}$ & 2.73 \\
\hline $\mathrm{C}$ & 0.00 \\
\hline $\mathrm{W}$ & \\
\hline
\end{tabular}

Figure 6

\begin{tabular}{|c|c|c|c|}
\hline & \multicolumn{2}{|c|}{ Rate of Return } \\
\hline Fund & Reported & True & Static Adj. \\
\hline N & 12.71 & 20.77 & 16.84 \\
\hline U & 12.40 & 19.51 & 12.92 \\
\hline S & 18.13 & 24.25 & 10.70 \\
\hline AA & 7.92 & 3.48 & 8.53 \\
\hline K & 76.20 & 68.91 & 8.12 \\
\hline P & 48.80 & 45.67 & 6.90 \\
\hline DD & 33.55 & 34.45 & 5.94 \\
\hline X & 71.79 & 62.19 & 5.78 \\
\hline KK & 13.19 & 15.66 & 5.49 \\
\hline CC & 49.59 & 47.55 & 5.30 \\
\hline C & 8.93 & 11.03 & 2.99 \\
\hline
\end{tabular}

Figure 7

\begin{tabular}{|c|c|c|c|c|c|}
\hline & \multicolumn{3}{|c|}{ Rate of Return } & \multicolumn{2}{c|}{ Static Adj. as a \% of: } \\
\hline Fund & Reported & True & Static Adj. & Reported & $81.08 \%$ \\
\hline N & 12.71 & 20.77 & 16.84 & $132.49 \%$ & $75.60 \%$ \\
\hline U & 12.40 & 19.51 & 14.75 & $118.95 \%$ & $53.28 \%$ \\
\hline S & 18.13 & 24.25 & 12.92 & $71.26 \%$ & $307.47 \%$ \\
\hline L & 7.92 & 3.48 & 10.70 & $135.10 \%$ & $12.38 \%$ \\
\hline AA & 76.20 & 68.91 & 8.53 & $11.19 \%$ & $17.78 \%$ \\
\hline P & 48.80 & 45.67 & 8.12 & $16.64 \%$ & $20.03 \%$ \\
\hline DD & 33.55 & 34.45 & 6.90 & $20.57 \%$ & $9.55 \%$ \\
\hline M & 71.79 & 62.19 & 5.94 & $8.27 \%$ & $36.91 \%$ \\
\hline X & 13.19 & 15.66 & 5.78 & $43.82 \%$ & $11.55 \%$ \\
\hline KK & 49.59 & 47.55 & 5.49 & $11.07 \%$ & $48.05 \%$ \\
\hline C & 8.93 & 11.03 & 5.30 & $59.35 \%$ & $25.06 \%$ \\
\hline W & 10.47 & 11.93 & 2.99 & $28.56 \%$ & $11.87 \%$ \\
\hline
\end{tabular}

In only one case was the static adjustment negligible. For the other thirteen funds examined, the static adjustment was, on average, was more than $50 \%$ of both the reported returns $(51.47 \%)$ and true returns $(54.66 \%)$. For only one of those funds was the adjustment even less than $10 \%$ of the reported and true returns. 


\section{CONCLUSION}

For an investor in an alternative investment fund, the only consideration is how much money is contributed compared to how much money is received in return. During the lifetime of the fund, an alternative asset manager will often market a new fund. An investor's decision as to whether or not to invest in the new fund depends largely on how well the current fund is performing. This has led many skeptics to conclude that alternative investment managers have an incentive to and, in fact, do overstate the interim rates of return.

A previous study found that such an overstatement of returns occurred in a little less than half of the funds examined. For the funds where it was concluded that the alternative asset manager did overstate the returns, in most cases the overstatement tended to be minor in nature. This paper examined the issue from a different perspective, and the empirical results have led us to a more definitive conclusion. Using the same set of 14 alternative asset funds as the previous study, we found that every single fund under consideration needed a positive static adjustment to be made to the reported return in order to get the cash flows to zero out at the end. Only one fund needed a negligible quarterly adjustment (.4\%), whereas all of the other funds but one needed a quarterly addition which represented more than $10 \%$ of the reported and true returns. Even the fund with the second lowest quarterly addition (2.73\%) was one for which the addition represented more than $10 \%$ of the reported and true returns

The results of the current study lead us to conclude that, contrary to popular belief, alternative asset managers actually tend to under-report quarterly rates of return.

\section{AUTHOR INFORMATION}

Jeffry Haber, PhD, CPA is Professor of Accounting and Chair of the Accounting Department at Iona College, teaching undergraduate and graduate classes in a variety of accounting areas. He publishes in the areas of investments, anti-money laundering and terrorist financing, earnings quality, ethics, bankruptcy prediction and other areas of financial and managerial accounting. Haber received a BS and MS from Syracuse University and a PhD from Rensselaer Polytechnic Institute and is a CPA licensed in New York. He is a frequent speaker at academic, professional, investment and accounting conferences. Haber is also Controller of the Commonwealth Fund, a private foundation seeking to move the United States towards a high performance health care system that achieves better access, improved quality, and greater efficiency. The Fund is a value-added foundation - conducting intramural research, working closely with grantees in designing, publishing, and communicating the results of projects, and conducting a web-based and media-oriented communications program aimed at reaching influential health policy and practice audiences. The Commonwealth Fund has $\$ 650$ million under investment.

Andrew Braunstein, $\mathrm{PhD}$ is a professor of business economics in the Hagan School of Business at Iona College, where he is currently in his 33rd year of fulltime service. He received a Ph.D. in economics from Rutgers University. The majority of his research and publication activity has involved the application of econometric techniques to issues in business, economics, and education.

\section{REFERENCES}

1. Gultz, Felix and Schroder, David (2010). Hedge fund transparency: Where do we stand? Journal of Alternative Investments, pp. 20-35, Vol. 12, No. 4, Spring 2010.

2. Haber, J., A. Braunstein \& G. Mangiero (2010). Do the unrealized gains in alternative investments ever become realized? Journal of Investing, pp. 49-52, Vol. 19, No. 2, Summer 2010.

3. Haber, J., A. Braunstein \& G. Mangiero (2011). The accuracy of the rates of return reported by fund managers: A test in the U.S. International Journal of Management, forthcoming

4. PriceWaterhouseCoopers (2008). Transparency versus returns: The institutional investor view of alternative assets, March 2008.

5. Thollot, Stephan (2010). Opinion: Push for transparency puts spotlight on valuation for alternative asset managers, Reuters Hedgeworld, October 2010. 